\title{
"STRUCTURED TEACHING PROGRAMME ON KNOWLEDGE REGARDING CARDIO PULMONARY RESUSCITATION AMONG IV YEAR B.SC. NURSING STUDENTS OF SELECTED NURSING COLLEGES AT TUMKUR, KARNATAKA WITH A VIEW TO DEVELOP AN INFORMATIONAL BOOKLET"
}

\author{
MR. LIBIN JOSEPH
}

Assistant Professor, B.C.M. College of Nursing, Sitapur, Uttar Pradesh, India

\begin{abstract}
One of the major causesfor death is sudden cardiac death in many countries. Defibrillation and other advanced life support measures are not immediately available in many situations. Professional helps are not easily available especiallyin urban settings. Educated and skilled bystanders can perform CPR (cardio pulmonary resuscitation)in these situations tosave life of many.So it is an important responsibility of educators to pass the knowledge and skills of CPR to their trainees, which may help to manage a stressful situation. It has been proved that if CPR performed correctly, may positively influence survival of cardiac arrest victims.

KEYWORDS: Cardio Pulmonary Resuscitation, IV Year B.Sc. Nursing, Informational Booklet, Cardiac Death, Defibrillation, Structured Teaching Programme
\end{abstract}

Received: Aug 08, 2020; Accepted: Aug 28, 2020; Published: Nov 06, 2020; Paper Id.: IJESRAUG202015

\section{INTRODUCTION}

Cardio (of the heart) pulmonary (of the lungs) resuscitation (to revert) is a medical term that used to denote restarting of temporarily stopped heart \& lungs function. CPR can help a person who has stopped breathing and heart beating, to stay alive. Those who are confront with emergency situationslike police officers, fire \& safety officers, lifeguards, doctors, nurses, paramedics, ambulance staffs etc. are all required to do training in CPR. Not only the persons who handle emergencies, but also nursing students, teachers, child care workers, parents etc. also must do training in CPR.

The professionals who are working hospital settings should be knowledgeable and skilled in CPR procedure, because cardiac arrest may occur at any time or setting that leads to cessation of breathing and heart function. There are two componentsof resuscitation measures- basic cardiac life support (BCLS) and advanced cardiac life support (ACLS). The standards for CPR are established by "The American Heart Association" and are actively involved in training BCLS and ACLS to every health professionals. Theyrecommendcertification in BCLS and ACLSfor nurses and physicians. Formal classes, cognitive and motor skill tests are involved in certification. Remember, CPR alone is not enough for saving lives of cardiac arrest victims. It plays as a vital part in the survival chain that helps the victim to meet advanced help. The survival chain composed of following: activation of EMS system, CPR, defibrillation and advanced care.

\section{OBJECTIVES OF THE STUDY}


- $\quad$ To check the existing knowledge of students on CPR(cardio pulmonary resuscitation).

- $\quad$ To check the posttest knowledge score of students on CPR (cardio pulmonary resuscitation).

- $\quad$ To find out significant differences between pre \&posttest knowledge scores.

- To find out the association of posttest knowledge score with selected demographic variables

- To develop an informational booklet.

\section{RESEARCH METHOD}

The research of the study was pre-experimental anddesign was one group pretest-posttest. The selected population wasIV yearB.Sc. nursing students. The sample consists of 60 students from Sri Ramanamaharshi College of Nursing, Sridevi College of Nursingand Aruna College of Nursing, Tumkur Karnataka. Purposive sampling was used for selection of students. The pretest conducted and after that STP was given to the students. After a week of pretest, the posttest was conducted with questionnaire schedule with the same questionnaire. Descriptive and inferential statistics were used to analyse the data.

\section{RESEARCH DESIGN}

\begin{tabular}{|c|c|c|c|}
\hline Population & 01 & $\mathbf{X}$ & $\mathbf{O 2}$ \\
\hline & $\begin{array}{c}\text { Pretest } \\
\text { ON } 1^{\text {ST DAY }}\end{array}$ & $\begin{array}{l}\text { Intervention } \\
\text { ON } 1^{\text {ST }} \text { DAY }\end{array}$ & $\begin{array}{c}\text { Posttest } \\
\text { ON } 7^{\mathrm{TH} D A Y}\end{array}$ \\
\hline $\begin{array}{l}\text { IV Year B.Sc. } \\
\text { nursing students } \\
\text { studying in selected } \\
\text { nursing colleges at } \\
\text { Tumkur. } \\
\text { Sample size } \mathbf{- 6 0}\end{array}$ & $\begin{array}{l}\text { Knowledge } \\
\text { Assessment by using } \\
\text { structured } \\
\text { questionnaire regarding } \\
\text { CPR. }\end{array}$ & $\begin{array}{lr}\text { Administration of } \\
\text { structured } & \text { teaching } \\
\text { program regarding } \\
\text { CPR. }\end{array}$ & $\begin{array}{l}\text { Assessment of knowledge and } \\
\text { skills by the same structured } \\
\text { questionnaire and check list } \\
\text { regarding CPR. }\end{array}$ \\
\hline
\end{tabular}

\section{RESULTS}

The data analysis was based on the study objectives and hypotheses. Descriptive and inferential statistics were mean, mean percentage,frequency, and standard deviation with tabular presentation of the data. Paired ' $t$ ' test was used to compare the knowledge scores of pretest and posttest. For finding the association of selected variables with posttest knowledge and skills scores, $\chi^{2}$ test was used.

The study findings revealed that $33.33 \%$ of students were belongs to $21-22$ years age group; $41.67 \%$ of students were belongs to 23-24 years age group and $25 \%$ of students were belongs to above 25 years age group. In the study $63.33 \%$ of female nursing students and $36.67 \%$ of male nursing students were participated. $56.67 \%$ respondents were Hindus, $10 \%$ were Muslims and $33.33 \%$ of respondents were Christians. $30 \%$ of participants belongto family with monthly incomebelow Rs.10,000/- and 70\% belongto family with monthly incomeabove Rs.10,000/-. Forty seven percent of the participants previously attended CPR classes and 53\% hadnot attended. The study included 33.33 \% of B.Sc. NursingIV year students from Sridevi College of Nursing, Sri Ramanamaharshi College of Nursingand Aruna College of Nursing, 
Tumkur, Karnataka respectively.

The mean knowledge score ofpretest was 16.55, and that of posttest was 32.47. Standard deviation of pretest is 3.784 and for posttest is $\mathbf{1 . 2 2 8}$. The mean skills score ofpretest was $\mathbf{5 . 1 3}$, and that ofposttest was 7.15. Standard deviation of pretest is $\mathbf{0 . 7 4}$ and for posttest is $\mathbf{0 . 3 6}$. This indicates that, the STP was effective in increasing the knowledge as well as skills regarding CPR for B.Sc. nursing IV year students.

Chi-square computed between posttest knowledge scores ofIV year B.Sc.Nursing students with their selected demographic variable: $\quad \mathrm{N}=60$

\begin{tabular}{|c|c|c|c|c|c|c|}
\hline \multirow{2}{*}{\multicolumn{2}{|c|}{ Variables }} & \multicolumn{2}{|c|}{ Knowledge } & \multirow[b]{2}{*}{ Chi Square } & \multirow[b]{2}{*}{ df } & \multirow[b]{2}{*}{ Inference } \\
\hline & & $\begin{array}{c}\text { Below } \\
\text { median }\end{array}$ & Above median & & & \\
\hline $\begin{array}{l}1 . \\
\text { a. } \\
\text { b. } \\
\text { c. }\end{array}$ & $\begin{array}{l}\text { Age } \\
21-22 \text { years } \\
23-24 \text { years } \\
>25 \text { years }\end{array}$ & $\begin{array}{l}11 \\
14 \\
6\end{array}$ & $\begin{array}{c}9 \\
11 \\
9\end{array}$ & 3.662 & 2 & $\mathrm{~S}$ \\
\hline $\begin{array}{l}2 . \\
\text { a. } \\
\text { b. }\end{array}$ & $\begin{array}{l}\text { Gender } \\
\text { Male } \\
\text { Female }\end{array}$ & $\begin{array}{c}22 \\
9 \\
\end{array}$ & $\begin{array}{l}16 \\
13 \\
\end{array}$ & 1.069 & 1 & NS \\
\hline $\begin{array}{l}3 . \\
\text { a. } \\
\text { b. } \\
\text { c. }\end{array}$ & $\begin{array}{l}\text { Religion } \\
\text { Hindu } \\
\text { Christian } \\
\text { Muslim } \\
\end{array}$ & $\begin{array}{c}20 \\
8 \\
3 \\
\end{array}$ & $\begin{array}{c}14 \\
12 \\
3 \\
\end{array}$ & 1.794 & 2 & NS \\
\hline & $\begin{array}{l}\text { me } \\
\text { Less than } 10,000 \\
\text { More than } 10,000\end{array}$ & $\begin{array}{c}9 \\
23\end{array}$ & $\begin{array}{c}9 \\
19\end{array}$ & 0.12 & 1 & NS \\
\hline & us classes attended & $\begin{array}{l}10 \\
18\end{array}$ & $\begin{array}{l}18 \\
12\end{array}$ & 4.55 & 1 & $\mathrm{~S}$ \\
\hline
\end{tabular}

\section{$\mathrm{S}=$ Significant, $\mathrm{NS}=$ Not Significant}

Chi-square computed between posttest skills scores of IV year BScnursing students with their selected demographic variables. $\quad \mathrm{N}=\mathbf{6 0}$

\begin{tabular}{|c|c|c|c|c|c|c|}
\hline \multirow{2}{*}{\multicolumn{2}{|c|}{ Variables }} & \multicolumn{2}{|c|}{ skills } & \multirow[b]{2}{*}{ Chi Square } & \multirow[b]{2}{*}{ df } & \multirow[b]{2}{*}{ Inference } \\
\hline & & $\begin{array}{c}\text { Below } \\
\text { median }\end{array}$ & Above median & & & \\
\hline $\begin{array}{l}\text { 1. Age } \\
\text { d. } \\
\text { e. } \\
\text { f. }\end{array}$ & $\begin{array}{l}\text { 21-22 years } \\
23-24 \text { years } \\
>25 \text { years }\end{array}$ & $\begin{array}{c}8 \\
15 \\
3\end{array}$ & $\begin{array}{l}12 \\
10 \\
12\end{array}$ & 8.321 & 2 & $\mathrm{~S}$ \\
\hline
\end{tabular}




\begin{tabular}{|c|c|c|c|c|c|}
\hline \begin{tabular}{|ll} 
2.Gender \\
c. & Male \\
d. & Female
\end{tabular} & $\begin{array}{c}18 \\
6\end{array}$ & $\begin{array}{l}20 \\
16\end{array}$ & 3.98 & 1 & $\mathrm{~S}$ \\
\hline \begin{tabular}{|ll} 
3. & Religion \\
d. & Hindu \\
e. & Muslim \\
f. & Christian
\end{tabular} & $\begin{array}{c}12 \\
2 \\
14\end{array}$ & $\begin{array}{c}22 \\
4 \\
6\end{array}$ & 0.962 & 2 & NS \\
\hline $\begin{array}{l}\text { 4. } \text { Income } \\
\begin{array}{ll}\text { c. } & \text { Less than } 10,000 \\
\text { d. } & \text { More than } 10,000\end{array}\end{array}$ & $\begin{array}{c}6 \\
20\end{array}$ & $\begin{array}{l}12 \\
22\end{array}$ & 1.86 & 1 & NS \\
\hline $\begin{array}{l}\text { 5. previous classes attended } \\
\text { a YES } \\
\text { b NO }\end{array}$ & $\begin{array}{l}6 \\
9\end{array}$ & $\begin{array}{l}12 \\
18\end{array}$ & 1.21 & 1 & NS \\
\hline
\end{tabular}

$\mathrm{S}=$ Significant, NS= Not Significant

\section{DISCUSSIONS}

All the peoples, especially the professionals who are working hospital settings should be aware and trained to do CPR procedure. There are two components of resuscitation measures- basic cardiac life support (BCLS) and advanced cardiac life support (ACLS). ACLS need equipment and advanced setting. Whereas BCLS need no such things, it needs a trained person. CPR can be done by a person alone or by the assistance of someone else. To perform CPR or to make assistance of common people, all persons especially health care professionals need to be trained. Such immediate and skilful actions can save life of many.

The pretest findings of the study revealed that the score were: mean 16.55, standard deviation 3.784 and mean score percentage was $37.61 \%$. And for skills the mean percentage is $51.33 \%$, standard deviation is 0.74 and mean is 5.13 . This shows that the knowledge and skills of nursing students regarding CPR was inadequate

After STP, the samples have showed improvement in the knowledge and skill of CPR.The scores in posttest are: mean 32.47, standard deviation was 1.228 and mean score percentage was $73.79 \%$. Hence the overall improvement in knowledge mean score is 15.93 . In posttest skills mean percentage is $71.5 \% \mathrm{SD}$ is 0.36 and mean 7.15 hence the overall improvement in skills mean percentage is 20.17

\section{INTERPRETATION AND CONCLUSIONS}

The study findings proved that, the knowledge and skills of nursing students regardingCPR in pretestwas inadequate. In this study, the structured teaching programme tested was found effective. The study proved that Age and previous CPR classes attended showed significant association with posttest score. Whereas religion, gender and family income are not significant, it also indicates the importance of frequent education programs to update the knowledge regarding CPR. 


\section{REFERENCES}

1. Harkness A Gail, Dincher R Judith, “Medical surgical Nursing”, $9^{\text {th }}$ edition, Mosby publishers, Page no 499-500.

2. Lewis Sharon Mantik, Collier Idolia Cox, Heitkemper Margaret, "Medical surgical Nursing”, volume-1, $4^{\text {th }}$ edition, Mosby publishers, Page no 991-992.

3. Anand, S. Vijay, and G. Dhanalakshmi. "Pre-Experimental Study to Assess the Effectiveness of Structured Teaching Programme on Knowledge Regarding Therapeutic Communication among Staff Nurses Working in Psychiatric Hospitals Chennai." International Journal of Medicine and Pharmaceutical Sciences (IJMPS) 7.2 (2017): 13-18.

4. Melissa Conrad, stopper, "Hands only CPR no more mouth to mouth?" Nurse education in practice volume 10, issue 5, page no 291-297.

5. NAGANANDINI, R. "EFFECTIVENESS OF STRUCTURED TEACHING PROGRAMME ON KNOWLEDGE REGARDING SELECTED ADOLESCENT BEHAVIORAL PROBLEMS AND ITS PREVENTION AMONG STUDENTS." Nursing (TJPRC: IJPN) 2.1 (2016): 1-8.

6. Denise K Polit \& Chery Tatano Beck, “Nursing Research”, $8^{\text {th }}$ edition, London, Lippincott Williams \&Wilkins, 2008 , pp757

7. 5.Drenzner JA, Rao AL, Heistands J, Bloomingdale M.K, Harmon, "Effectiveness of emergency response planning for sudden cardiac arrest in united states high schools with automated external defibrillators", circulation 2009 Aug. 11:120(6):518-25.

8. Lynn PRoppolo and Paul EPepe, "Retention: targeting the young in CPR skills training", critical care 2009 volume 13:185 doi: $10.1186 /$ cc 7997.

9. MAHMOOD, AZHAR, and IRFAN ASHRAF. "Peace Education: Conceptual awareness of Teachers at Elementary School Level." International Journal of Educational Science and Research, ISSN (P) (2014): 2249-6947.

10. 7. http://www.emedicine health.com/cardiopulmonary resuciation-cpr/article-em.htm.

11. 8. Wockhardt hospital guide to wellness, February 8, 2010 available on www.google.com

12. 9. Reder S, Quan L, “Cardio pulmonary resuscitation training in Washington state public high schools”, Resuscitation 2003 march 56(3):283-8.

13. MANNA, RAKESH, and JAYANTA METE. "Secondary teacher education system in India with special reference to West Bengal." International Journal of Humanities and Social Sciences 5.3 (2016): 97-111.

14. 10. Celenza T, Gennat HC, O Brein d, Jacobs IG, Lynch DM, Jelinek AK, "Community competence in cardio pulmonary resuscitation”, 2002, Nov 55 (2):157-65.

15. 11. Moule P,Knight C, "Emergency, Cardiac arrest! Can we teach the skill?” Nurse educ today 1997 Apr 17(2):99-105.

16. RANI, YEDIDI MERCY. "TASK BASED LANGUAGE TEACHING IN PROMOTING THE TARGET LANGUAGE CULTURE THROUGH IDIOMS AND PROVERBS-A CASE STUDY." International Journal of Linguistics and Literature (IJLL) 6. 1, Dec - Jan 2017; 1-10

17. 12. Todd J. Crocco, Raymond Moreno, Edward C. Jauch. Teaching ACLS on stroke. Pre hospital Emergency Care.2003, V. 7(2), P 229-234 

